\title{
THE OLD RUSSIAN WRITER \\ AND PREACHER OF 12th CENTURY, CYRIL OF TUROV ${ }^{1}$
}

\begin{abstract}
:
The article discusses the main milestones in the life and creative heritage of the outstanding writer of the Eastern Slavs, Bishop Cyril of Turov, as well as the history of the study of his work. He entered into the history of East Slav literature as an author of prayers, canons and homilies. His work's popularity surpassed similar writings of other old Slavic authors for centuries. His spiritual works still echo today in the orthodox folk songs in Belarus', Ukraine and Russia. Cyril of Turov is one of the most revered saints in Belarus': one can see monuments to him in many Belarusian cities.
\end{abstract}

\section{Keywords:}

Cyril of Turov, Old Rus', Orthodoxy, Old Russian literature, handwritten books, interSlavic cultural ties.

АННОТаЦИЯ: Ю.А. ЛАБЫНЦЕВ. «ДРЕВНЕРУССКИЙ ПИСАТЕЛЬ И ПРОПОВЕДНИК ХІІ В. КИРИЛЛ ТурОвСКИЙ».

В статье рассматриваются основные вехи жизни и творческое наследие выдающегося писателя Восточной Славии, Кирилла епископа Туровского. Анализируется в ней также и история изучения данной научной проблематики. Этот творец вошел в историю литератур восточных славян как автор молитв, похвал святым, канонов и поучений. По степени популярности его произведения превосходили аналогичные сочинения большинства других древнеславянских авторов на протяжении нескольких столетий. Сочиненные им молитвы и сегодня звучат в православной народной среде Беларуси, Украины и России. Кирилл Туровский является одним из самых почитаемых в Беларуси святых: памятники ему установлены во многих городах республики.

\section{Ключевые слова:}

Кирилл Туровский, Древняя Русь, православие, древнерусская литература, рукописная книжность, межславянские культурные связи.

Cyril of Turov - the saint, Bishop, outstanding writer of Eastern Slavia, author of prayers, praise of saints, canons, teachings. His works in terms of their popularity surpassed the works of other authors of antiquity for centuries. His prayers are still heard in the Orthodox communities of Belarus', Ukraine and Russia. Little information has been preserved about Cyril's life. The dates of his birth and death are unknown; he presumably died around 1183. In the Life of St Cyril of Turov, created several decades after his death, it is said: “... blessed Cyril was born and raised by the city ... of Turov in the Russian country ... a son of

\footnotetext{
1 The work was carried out with the financial support of the RFBR (grant № 18-512-76004).
} 
a rich parent." The compiler of his Life calls him "The Second Chrysostom" for his literary talent, which delighted contemporaries and their descendants: "Rejoice at the holy prelate, our teacher! The second Chrysostom shone for us more than anyone else ..."

Cyril took monastic vows in his hometown of Turov, became famous for his monastic deeds and theological works, and was supposedly elevated to episcopal dignity in 1159. After taking office, the new Bishop found himself in the midst of political struggle and church strife. Cyril denounced the heresies and the iniquity of princes and bishops capable of making a show of living honorable lives while openly deceiving the people. In the latter days of his life, Cyril left the episcopal ministry and continued his literary works in one of the Turov monasteries, possibly St Nicholas.

Cyril's hometown of Turov in the twelfth century was one of the most significant old Russian cities. The first mention of it dates back to 980: "Rovgolod came from overseas and exercised authority in Polotsk just as Tury, from whom the Turovians get their name, did in Turov." Archaeological excavations have shown that a large settlement near the present Turov may have developed much earlier than this. In the tenth century. it was a major economic and cultural center, the capital city of the Principality of Turov. Here arose one of the first bishoprics in Russia, to which many cities and neighboring villages were given into its keeping. At the end of the eleventh and the beginning of the twelfth centuries. the Greek Princess Barvara, wife of Prince Svyatopolk Izyaslavich, founded the Barvara monastery for women in Turov. On the site of the ancient city, archaeologists have discovered the remains of numerous buildings, a stone cathedral, stone sarcophags and many cultural artefacts. The latter speak of the wide economic and cultural ties of Turov and the Turov' region with the Black Sea, the Baltic states and the East. In the center of the city was the princely palace; to the south - the Borisogleb' Cathedral; to the west of it - the episcopal or "ruler" courtyard in an elevated location.

In the Life of the saint, his writings are listed in detail, some of which have not survived: denunciation of the heresy of Bishop Theodore, numerous letters to Prince Andrey of Bogolyubovo and praise to many saints, the Great Penitential Canon with the arrangement of verses in alphabetical order and other works.

Among the old Slavic authors of Eastern Slavia, Bishop Cyril of Turov was perhaps the most prolific, especially given the writings attributed to him. Unfortunately, despite a relatively long study of the creative heritage of the scribe, an accurate list of his works and their manuscripts has not yet been created. Cyril's authorship has been established for only a few epistles and teachings (some of which are known only by name), several sermons, about 30 prayers and two canons.

The earliest extant lists of Cyril's works date back to the 13th century. Over time, the number of such lists gradually increased in both East Slavic and South Slavic lands. Particularly noteworthy is the fact of the wide distribution of handwritten lists of the prelate's works among the Southern Slavs in the 16th -17 th 
centuries. In the following century, Cyril's prayers began to be actively rewritten by Russian Old Believers. Cyril's works were printed in the second half of the 16 th century and published in greater number in the first third of the next century. In summary, these were prayers and "a sermon by 'the unworthy monk Cyril' on the Ascension Day on the fourth day of the sixth week after Easter, from the prophetic precepts and about the resurrection of the Universal Adam."

Until the end of the 16th century, Cyril's most widely read and distributed works were the hymnographic and some homiletic works. After that there was a surge of interest in the prayers of the ascetic, which has not dried up to this day. In 1596, in Vilna, in the printing house of the Orthodox Brotherhood of the Holy Spirit, a collection was published of "Everyday prayers by many of the Church Fathers, Christian teachers, chosen from Greek writings, and other prayers for the week of St Cyril, the cenobite." This edition was published during a period of tragic unrest in church life, in the year of the adoption of the Church Union of Brest. It served as a model and basis for many subsequent editions in the 17 th 20 th centuries. Intended for a wide range of Orthodox, primarily laypeople, it brought the prayers of Cyril to many people and many generations.

This publication marked the beginning of a new life for Cyril's prayers and the advent of a new era of their spread among the Orthodox. The texts of the prayers placed in it formed the basis for the publication of a second edition in 1880. It was carried out by an expert on the writings of the saint, Bishop Eugene (Shereshilov) of Minsk, who, together with his colleagues, believed that Cyril's prayers constituted the best part of his works. According to him, they entered church and folk use due to their detachment from conventional influences of place and time, had a wide and beneficial effect on Russian Christians. They can therefore be considered "the best of the existing prayers in church usage." The famous Russian writer N.S. Leskov so appreciated and was inspired by the Cyril prayer cycle that he prepared and published his own edition of it in 1876 under the title "Prayer offerings to God of our holy father Cyril, Bishop of Turov." The book contains an epigraph that allows us to understand how the writer perceived the essence of Cyril's literary creativity: "Not to pray only for ourselves, but also for strangers and enemies, not just for Christians, but also for adherents of different faiths, so that they would turn to God."

Orthodox monasticism has always honored the works of Cyril, especially his prayer cycle. From the prayers of the ascetic, the monks composed a whole book, which they rewrote until the 19th century. Thanks to this, there was a source base for studying the work of Cyril. From the very beginning of the development of Slavic studies as an academic area, researchers drew attention to the literary talent of the saint. The significance of Cyril's work for the history of Slavic culture and his excellent knowledge of Christian literature at that time were appreciated. According to the Church calendar, Cyril's commemoration falls on 28th or 30th of April. In the 1870s Bishop Eugene of Minsk and Turov strengthened the veneration of Cyril: the saint became the patron saint of the Minsk diocese. 


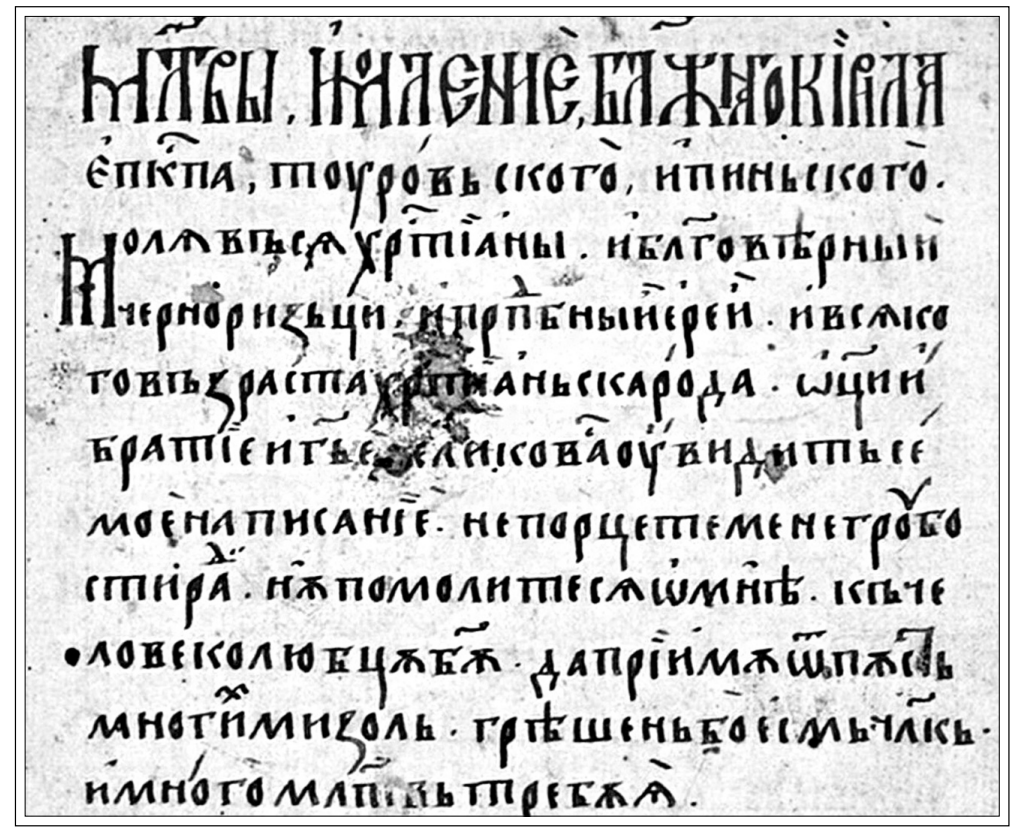

The title page with the prayers of Cyril of Turov, manuscript of the 15 th century. Kiev, National Library of Ukraine named after V. I. Vernadsky, Institute of manuscripts. F. 1. st. u. 5357

In 1984, when the celebration of the Synaxis of the Belarusian Saints was established, our saint was among them. Now the name of Cyril is carried by the Minsk Theological Academy and the public scientific society in the city of Gomel, and in his honor a church order and a medal have been established. Every year on 11 May (April 28th, according to the old style), a celebration in memory of the saint with a procession is held in the saint's hometown of Turov.

No reliable images and descriptions of the appearance of Cyril have been found. However, iconographic scripts describe him as follows: “...elderly, very clever and gentle; with a small round beard, simple hair, a thin face; in chasuble and omophorion, a hat with an embroidered cross on his head, a book in his hands." One of the earliest surviving iconographic images of Cyril dates back to the beginning of the 19th century. Then, apparently, there were only a few, but by the end of the century there were many more of them. Today this saint is one of the most revered Belarusian saints. His images exist not only on icons, but also on secular paintings and graphic works. Monuments were erected to him in a number of Belarusian cities. One of them is located in the center of Turov, the other is on the territory of the Belarusian State University of Minsk, the third is in the centre of the city of Gomel. 


\section{BIBLIOGRAPHY}

Eremin I.P. Literaturnoe nasledie Kirilla Turovskogo // TODRL. T. 11. Moscow-Leningrad, 1955. S. 342-357.

Hryniewicz W. Staroruska teologia paschalna w świetle pism św. Cyryla Turowskiego.

Warszawa, 1993.

Tvoreniia sviatogo ottsa nashego Kirilla episkopa Turovskogo. Kiev, 1880.

\section{ILLUSTRATIONS}

1. The beginning of a prayer "On Friday" by Cyril of Turov, manuscript of 13th century. Moscow, State Historical Museum, Department of manuscripts, collection of E. V. Barsov, N. 347.

2. The title page with the prayers of Cyril of Turov, manuscript of the $15 \mathrm{th}$ century. Kiev, National Library of Ukraine named after V. I. Vernadsky, Institute of manuscripts. F. 1, st. u. 5357.

3. Page of the printed Zabludov Gospel with the "Word for Ascension" by Cyril of Turov, 1569.

4. The title page of "Everyday Prayers" with a cycle of prayers by Cyril of Turov. Vilno, 1596.

5. The title page of "Prayers for the whole Week" by Cyril of Turov in the book "Everyday Prayers". Vilno, 1596.

6. Modern icon of Cyril of Turov, private collection.

7. Monument to Cyril of Turov in the city of Turov. Sculptor M. Melnikov. 1993.

8. Monument to Cyril of Turov in Minsk. Sculptor A. Prokhorov. 2001.

9. Monument to Cyril of Turov in Gomel. Sculptors L. N. Gumilevsky and S. L. Gumilevsky, 2004.

10. Order of Cyril of Turov of Belarusian Exarhate of the Russian Orthodox Church. 